\title{
Depressed Tolbutamide-Induced Insulin Response in Subjects Treated with Propranolol*
}

\author{
F. Massara, E. Strumia, F. Camanni and G.M. Molinatti \\ Istituto di Clinica Medica dell'Università di Torino, Italy \\ Received: April 1, 1971, accepted: May 28, 1971
}

\begin{abstract}
Summary. The effect of propranolol on $1 \mathrm{~g} \mathrm{i} . \mathrm{v} . \mathrm{tol}-$ butamide-induced insulin response was studied in 11 subjects. The drug depressed this response, the effect being more noticeable in the patients receiving $200 \mathrm{mg} /$ day per os for three days. The corresponding blood glucose curves, however, were unaffected by propranolol. The finding suggest that the beta-receptors play a part in sulphonylurea-induced insulin secretion in man.

Réduction de la libération de l'insuline produite par la tolbutamide chez des patients traités par propranolol

Résumé. Les Auteurs ont examiné chez l'homme (11 patients) l'effet du propranolol sur la libération de l'insuline produite par la tolbutamide (1 g par voie endoveineuse). Les résultats montrent que le propranolol réduit l'augmentation de l'insulinémie due à la tolbutamide. Ce phénomène est plus évident chez les patients traités par desdoses de $200 \mathrm{mg}$ per os, par jour, pendant trois jours de suite. D'autre part, les courbes glycémiques correspondan tes ne sont pas modifiées significativement par cette administration de propranolol. Ces observations suggèrent
\end{abstract}

que chez l'homme les bêta-récepteurs jouent un rôle dans les mécanismes de libération de l'insuline produite par les sulphonylurées.

Herabsetzung der durch Tolbutamid verursachten Insulinsekretion bei mit Propranolol behandelten Patienten

Zusammenfassung. Die Verfasser untersuchten bei 11 Pationten die Wirkung von Propranolol auf die durch $1 \mathrm{~g}$ intravenös verabreichtes Tolbutamid verursachte Insulinsekretion. Die Ergebnisse zeigen, daß Propranolol die Zunahme der durch Tolbutamid verursachten Insulinämie vermindert und dies ganz besonders bei jenen Patienten, welche mit Dosen von $200 \mathrm{mg}$ per os pro Tag an 3 aufeinanderfolgenden Tagen behandelt wurden. Die ent. sprechenden Glycämiekurven wurden jedoch durch Pro. pranololverabreichung nicht bedeutend verändert. Diese Befunde deuten darauf hin, daß beim Mensehen die BetaReceptoren bei der durch Sulphonylurea verursachten Insulinsekretion eine Rolle spielen.

Key-words: Tolbutamide, plasma insulin, propranolol.
In man, stimulation of beta-adrenergic and alphaadrenergic receptors increases blood insulin levels and inhibits secretion respectively $[10,11]$. Beta-receptors seem also to be involved in glucose- [3] but not in glucagon-induced [10] insulin release mechanisms. The present paper investigates the effect of propranolol, a beta-receptor blocking substance on the insulin response to tolbutamide.

\section{Materials and Methods}

Following an overnight fast, 5 normal and 2 slightly obese women and 4 normal men, aged from 23 to 48 yr (some with small non-toxic goitres) on a diet containing at least $200 \mathrm{~g}$ carbohydrate per day were subjected at 9 a.m. to 2 tests at three-day-intervals. In the first test, $1 \mathrm{~g}$ tolbutamide (Rastinon diagnostic test, Hoechst) was given i.v. in one minute; in the second, tolbutamide was preceded by propranolol (Inderal, I.C.I.) according to two modalities:

* Part of this study has been presented at the 3 th Congress of Italian Association for the study of Diabetes (Modena, Aprile 1970), and accepted in abstract form (by title) at the 7 th Congress of the International Diabetes Federation.
1. 5 subjects received $200 \mathrm{mg} /$ day orally for three days in 4 administrations; the last tablet was given $1 \mathrm{~h}$ before tolbutamide.

2. 6 patients received $10 \mathrm{mg}$ propranolol in $100 \mathrm{ml}$ saline solution i.v. in $10 \mathrm{~min}$ before the tolbutamide (in the first test, these subjects received the $100 \mathrm{ml}$ saline solution only).

For blood sugar (method of Somogyi \& Nelson [9]) and plasma insulin (radio-immunological method: CEA CEN Sorin kit) determination specimens were withdrawn immediately before and $2^{\prime}, 5^{\prime}, 15^{\prime}, 30^{\prime}, 45^{\prime}$ and $60^{\prime}$ after the commencement of the tolbutamide injection; with i.v. propranolol, the $5^{\prime}$ withdrawal was not done. Plasma insulin determinations for the two tests were made simultaneously for the same subject.

\section{Results}

Basal insulin values were not influenced by propranolol (Tables 1, 2).

Oral propranolol ( $200 \mathrm{mg} /$ day) was always followed by a marked reduction in insulin response to tolbutamide in the first $15 \mathrm{~min}$ (Table 1, Fig. 1), with a mean curve depression that was significant at $5^{\prime}$ and $15^{\prime}(P<0.05$, paired $t$-test $)$. 
Table 1. Blood glucose and plasma insulin response to tolbutamide before and after oral 200 mg/day propranolol for three days

\begin{tabular}{|c|c|c|c|c|c|c|c|c|c|c|c|c|c|c|c|c|}
\hline \multirow[t]{2}{*}{ Case } & \multirow{2}{*}{\multicolumn{2}{|c|}{ Name age sex }} & \multicolumn{7}{|c|}{ before } & \multicolumn{7}{|l|}{ after } \\
\hline & & & B. & $2^{\prime}$ & $5^{\prime}$ & $15^{\prime}$ & $30^{\prime}$ & $45^{\prime}$ & $60^{\prime}$ & B. & $2^{\prime}$ & $5^{\prime}$ & $15^{\prime}$ & $30^{\prime}$ & $45^{\prime}$ & $60^{\prime}$ \\
\hline & & & \multicolumn{14}{|c|}{ Blood Glucose $\mathrm{mg} / 100 \mathrm{ml}$} \\
\hline 1 & B.A.M. ${ }^{\mathrm{a}}$ & $30 \mathrm{~F}$ & 90 & 90 & 87 & 79 & 55 & 52 & 58 & 93 & 93 & 93 & 82 & 61 & 55 & 67 \\
\hline 2 & B.A. & $44 \mathrm{~F}$ & 85 & 79 & 82 & 72 & 61 & 49 & 52 & 93 & 87 & 87 & 79 & 61 & 52 & 61 \\
\hline 3 & N.G. & $23 \mathrm{M}$ & 90 & 87 & 90 & 61 & 31 & 54 & 73 & 87 & 82 & 85 & 72 & 48 & 49 & 64 \\
\hline 4 & E.M. & $35 \mathrm{~F}$ & 87 & 90 & 87 & 79 & 58 & 55 & 61 & 85 & 83 & 83 & 79 & 55 & 54 & 63 \\
\hline \multirow[t]{2}{*}{5} & C.S.G. ${ }^{a}$ & $42 \mathrm{~F}$ & 93 & 90 & 90 & 85 & 61 & 58 & 73 & 93 & 90 & 87 & 82 & 67 & 67 & 70 \\
\hline & \multicolumn{2}{|c|}{ Mean \pm S.E.M. } & $\begin{array}{l}89+\frac{t}{1} \\
1.37\end{array}$ & $\begin{array}{l}87 \pm \\
2.1 \frac{1}{3}\end{array}$ & $\begin{array}{l}87 \pm \\
1.46\end{array}$ & $\begin{array}{l}75 \pm \\
4.10\end{array}$ & $\begin{array}{l}53 \pm \\
5.66\end{array}$ & $\begin{array}{l}53 \pm \\
1.50\end{array}$ & $\begin{array}{l}63 \pm \\
4.17\end{array}$ & $\begin{array}{l}90 \neq \\
1.7 \frac{7}{4}\end{array}$ & $\begin{array}{l}87 \pm \frac{ \pm}{2.07}\end{array}$ & $\begin{array}{l}87 \pm \\
1.67\end{array}$ & $\begin{array}{l}78 \pm \\
1.82\end{array}$ & $\begin{array}{l}52 \neq \\
3.21\end{array}$ & $\begin{array}{l}55 \pm \\
3.07\end{array}$ & $\begin{array}{l}65 \pm \\
3.5 \overline{3}\end{array}$ \\
\hline & & & Plas & na Inst & $\operatorname{lin} \mu$ & $\mathrm{J} / \mathrm{ml}$ & & & & & & & & & & \\
\hline $1^{\mathrm{a}}$ & & & 57 & 302 & $188^{\circ}$ & 176 & 110 & 73 & 76 & 44 & 128 & 121 & 141 & 87 & 53 & 80 \\
\hline 2 & & & 36 & 98 & 140 & 120 & 54 & 52 & 32 & 30 & 35 & 102 & 62 & 60 & 42 & 28 \\
\hline 3 & & & 38 & 177 & 164 & 124 & 59 & 58 & 41 & 36 & 78 & 148 & 102 & 46 & 42 & 43 \\
\hline 4 & & & 34 & 102 & 164 & 114 & 62 & 56 & 64 & 38 & 90 & 70 & 80 & 50 & 46 & 45 \\
\hline $5^{\mathrm{a}}$ & & & 42 & - & 166 & 180 & 76 & 72 & 42 & 36 & - & 126 & 94 & 56 & 52 & 62 \\
\hline \multicolumn{3}{|c|}{ Mean \pm S.E.M. } & $\begin{array}{l}41 \pm \\
4.11\end{array}$ & $\begin{array}{r}169 \pm \\
47.6\end{array}$ & $\begin{array}{c}164 \pm \\
7.60\end{array}$ & $\begin{array}{l}142+\frac{1}{14.47}\end{array}$ & $\begin{array}{c}72 \pm \\
10.13\end{array}$ & $\begin{array}{l}62 \pm \\
4.31\end{array}$ & $\begin{array}{l}51 \neq \\
8.17\end{array}$ & $\begin{array}{l}37 \frac{1}{ \pm} \\
2.24\end{array}$ & $\begin{array}{r}82 \pm \\
19.15\end{array}$ & $\begin{array}{l}113 \pm \\
13.09\end{array}$ & $\begin{array}{r}96+ \\
13.18\end{array}$ & $\begin{array}{l}59 \pm \\
7.21\end{array}$ & $\begin{array}{l}47 \pm \\
2.36\end{array}$ & $\begin{array}{l}51 \pm \\
8.91\end{array}$ \\
\hline
\end{tabular}

a Slightly obese

Table 2. Blood glucose and plasma insulin response to tolbutamide before and after i.v. $10 \mathrm{mg}$ propranolol

\begin{tabular}{|c|c|c|c|c|c|c|c|c|c|c|c|c|c|}
\hline \multirow[t]{2}{*}{ Case } & \multirow[t]{2}{*}{ Name ag'e sex } & \multicolumn{6}{|l|}{ before } & \multicolumn{6}{|l|}{ after } \\
\hline & & B. & $2^{\prime}$ & $15^{\prime}$ & $30^{\prime}$ & $45^{\prime}$ & $60^{\prime}$ & B. & $2^{\prime}$ & $15^{\prime}$ & $30^{\prime}$ & $45^{\prime}$ & $60^{\prime}$ \\
\hline & & Blood & Glucose & $\operatorname{mg} \%$ & $100 \mathrm{ml}$ & & & & & & & & \\
\hline 6 & D.A. $25 \mathrm{~F}$ & 90 & 90 & 82 & 73 & 58 & 67 & 73 & 79 & 73 & 55 & 61 & 70 \\
\hline 7 & R.L. $35 \mathrm{M}$ & 85 & 85 & 73 & 51 & 48 & 65 & 85 & 85 & 76 & 52 & 52 & 64 \\
\hline 8 & P.M. 41 F & 73 & 70 & 55 & 22 & 38 & 49 & 96 & 93 & 85 & 61 & 54 & 73 \\
\hline 9 & C.G. $48 \mathrm{M}$ & 113 & 99 & 79 & 62 & 53 & 48 & 101 & - & 73 & 59 & 53 & 56 \\
\hline 10 & F.M. 31 F & 79 & 79 & 68 & 48 & 51 & 59 & 73 & 76 & 62 & 45 & 45 & 53 \\
\hline \multirow[t]{2}{*}{11} & S.A. 42 M & 79 & 85 & 73 & 54 & 50 & 58 & 82 & 87 & 73 & 55 & 47 & 67 \\
\hline & Mean \pm S.E.M. & $\begin{array}{l}86 \pm \\
6.10\end{array}$ & $\begin{array}{l}84 \pm \\
4.01\end{array}$ & $\begin{array}{l}71 \pm \\
3.90\end{array}$ & $\begin{array}{l}51 \pm \\
7.00\end{array}$ & $\begin{array}{l}49 \pm \\
2.71\end{array}$ & $\begin{array}{l}57 \pm \\
3.22\end{array}$ & $\begin{array}{l}85 \pm \\
4.74\end{array}$ & $\begin{array}{l}84 \pm \\
3.00\end{array}$ & $\begin{array}{l}73 \pm \\
3.00\end{array}$ & $\begin{array}{l}54 \pm \\
2.31\end{array}$ & $\begin{array}{l}52 \pm \\
2.31\end{array}$ & $\begin{array}{l}64 \pm \\
3.22\end{array}$ \\
\hline & & Plasm & Insulin & $\mu \mathrm{U} / \mathrm{ml}$ & & & & & & & & & \\
\hline 6 & & 28 & 33 & 66 & 50 & 48 & 46 & 35 & 76 & 63 & 48 & 27 & 36 \\
\hline 7 & & 24 & 52 & 98 & 61 & 48 & 44 & 28 & 64 & 110 & 59 & 40 & 52 \\
\hline 8 & & 24 & 86 & 108 & 48 & 34 & 40 & 30 & 82 & 94 & 52 & 36 & 38 \\
\hline 9 & & 40 & 128 & 90 & 58 & 42 & 30 & 32 & 78 & 70 & 42 & 36 & 26 \\
\hline 10 & & 59 & 94 & 102 & 80 & 71 & 72 & 74 & 80 & 94 & 84 & 68 & 74 \\
\hline \multirow[t]{2}{*}{11} & & 42 & 90 & 70 & 51 & 41 & 40 & 40 & 72 & 74 & 56 & 42 & 42 \\
\hline & Mean \pm S.E.M. & $\begin{array}{l}36 \text { 士 } \\
5.58\end{array}$ & $\begin{array}{l}80 \pm \\
13.93\end{array}$ & $\begin{array}{l}89 \pm \\
7.09\end{array}$ & $\begin{array}{l}58 \pm \\
4.86\end{array}$ & $\begin{array}{l}47 \pm \\
5.19\end{array}$ & $\begin{array}{l}45 \pm \\
5.80\end{array}$ & $\begin{array}{l}40 \pm \\
7.06\end{array}$ & $\begin{array}{l}75 \pm \\
2.65\end{array}$ & $\begin{array}{l}84 \pm \\
7.35\end{array}$ & $\begin{array}{l}57 \pm \\
5.97\end{array}$ & $\begin{array}{l}41 \pm \\
5.72\end{array}$ & $\begin{array}{l}45 \pm \\
6.83\end{array}$ \\
\hline
\end{tabular}

Following i.v. propranolol (Table 2), the mean tolbutamide-induced increase curve was lower than the control curve. This difference was not significant for the paired data, however, owing to variations in the point of time at which the insulin increase was inhibited in the individual subject.

\section{Discussion}

Propranolol does not affect basal plasma insulin values.
The $200 \mathrm{mg} /$ day oral dose, normally employed therapeutically, is responsible for significant depression of insulin response to tolbutamide. Similar findings have been reported for tolbutamide in the rat [2] and for glybenclamide in the dog [12].

It has recently been shown [4] that, given equal plasma levels, propranolol is decidedly less active when administered intravenously as opposed to per os. The lesser effect observed with i. v. propranolol may be an outcome of the use of this route and/or of the doses employed. It cannot be excluded, however, that this 
lesser effect may also be due to the lesser response of blood insulin levels to tolbutamide observed, quite by chance, in this group of patients.

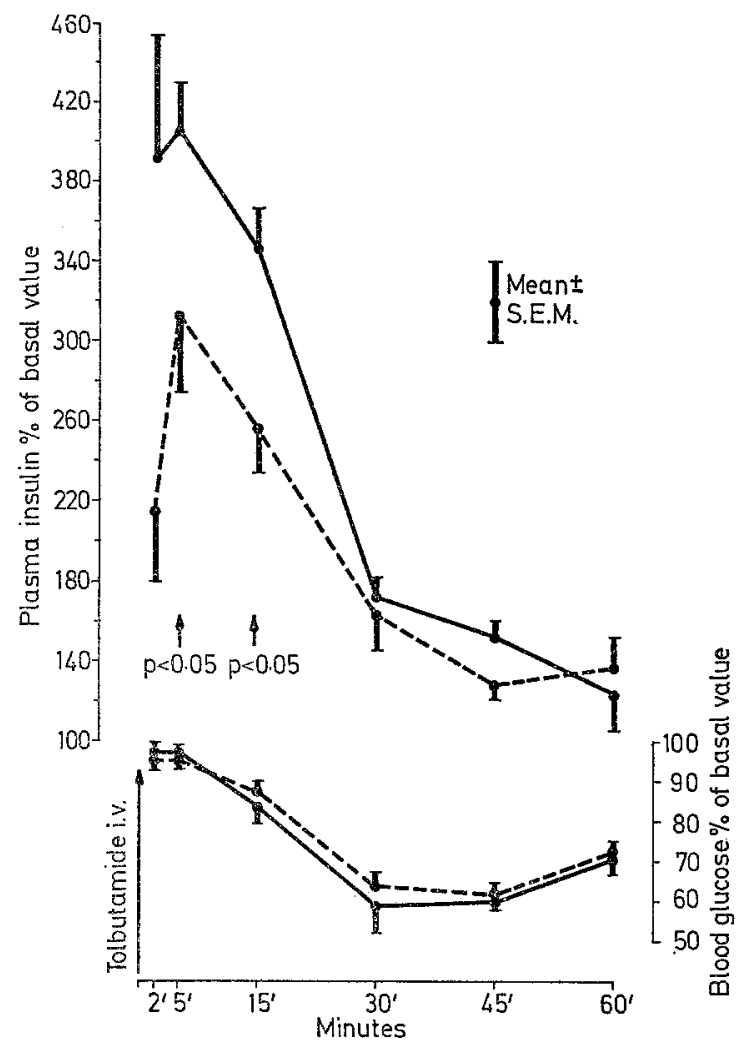

Fig. 1. Tolbutamide test in 5 subjects (3 normal, 2 slightly obese) before (-) and after (-.....) propranolol (200 $\mathrm{mg} /$ day for three days). $P=$ paired $t$-test

The findings suggest that the beta-adrenergic receptors play a part in sulphonylurea-induced increases in insulin secretion.

Depression of such increases as a result of endogenous catecholamine secretion is not a valid explanation here, since depression occurred within $5^{\prime}$ after tolbutamide, i.e. in a period where the absence of catecholamine activity could be deduced from the maintenance of unchanged blood sugar levels.

As suggested by Bressler et al. [2] for the rat, however, propranolol may perhaps inhibit the release of insulin by acting on the beta cells at different levels from those of the beta receptors. Nor must the possible interference of haemodynamic factors be overlooked.

As already shown in the rabbit [6] and the dog [12], the tolbutamide blood sugar curve was not significantly influenced by propranolol, although a smaller fall in values might have been expected as a consequence of decreased insulin secretion. This discrepancy may be partly explained by the fact that betareceptor block potentiates, albeit inconsistently in different subjects, the hypoglycaemic effects of insulin $[1,7,8]$.

Note should, however, be taken of the evidence, conflicting with the present data, namely the observation of reduced hypoglycaemic response to tolbutamide in man [5] following i. v. propranolol.

Our results are also of clinical interest, since the frequent association of diabetes and coronary disease means that patients may occasionally be subjected to simultaneous tolbutamide and propranolol treatment.

\section{References}

1. Abramson, E.A., Arky, R. A.: Role of beta-adrenergic receptors in counter-regulation to insulin-induced hypoglycemia. Diabetes 17, 141-146 (1968).

2. Bressler, R., Vargas-Cordon, M., Brendel, K. : Studies on the role of adenylcyclase in insulin secretion. Arch. intern Med. 123, 248-251 (1969).

3. Cerasi, E., Effendic, S., Luft, E.: Role of adrenergic receptors in glucose-induced insulin secretion in man. Lancet 1969 II, $301-302$.

4. Coltart, D.J., Shand, D.G.: Plasma propranolol levels in the quantitative assessement of beta-adrenergic blockade in man. Brit. med. J. 1970 III, 731 - 734.

5. De Divitiis, O., Gallo, B., Jacono A.: Tolbutamide and propranolol. Lancet $1968 \mathrm{I}, 749$

6. Erill, S.: Persistence of the hypoglycemic effect of tolbutamide after block of beta-adrenergic receptors. Arch. int. Pharmacodyn. 177, 287-289 (1969).

7. London, D.R., Prenton, M.A.: Beta-adrenergic receptors and the plasma amino acid response to insulin in man. Clin. Sci. 35, 55-61 (1968).

8. Massara, F., Camanni, F.: Propranolol block of adrenaline-induced hypophosphataemia in man. Clin. Sci. 38, 245-250 (1970).

9. Nelson, N.: A photometric adaptation of the Somogyi method for the determination of glucose. J. biol. Chem. 153, 375-380 (1944).

10. Porte, D. Jr.: Beta-adrenergic stimulation of insulin release in man. Diabetes 16, 150-155 (1967).

11. - A receptor mechanism for the inhibition of insulin release by epinephrine in man. J. clin. Invest. 46, 8694 (1967).

12. Sirek, O.V., Vigas, M., Niki, A., Niki, H., Sirek, A.: Beta-adrenergic stimulation and insulin release in dogs following HB 4 19. Diabetologia 5, 207-210 (1969).

Dr. F. Massara

Clinica Medica dell'Università

Corso Polonia 14

I-10126 Torino

Italia 